Historic, Archive Document

Do not assume content reflects current scientific knowledge, policies, or practices. 


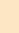


United States

Agriculture

Forest Service

Rocky Mountain

Forest and Range

Experiment Station

Fort Collins

Colorado 80526

General Technical

Report RM-255
Department of

The Status and Impact of State and Local Regulation on Private Timber Supply

\author{
John L. Greene and William C. Siegel
}

$\sqrt{405}$

\section{hnical}

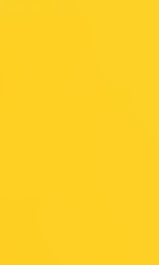




\begin{abstract}
Greene, John L.; Siegel, William C. 1994. The status and impact of state and local regulation on private timber supply. General Technical Report RM-255. Fort Collins, CO: U.S. Department of Agriculture, Forest Service, Rocky Mountain Forest and Range Experiment Station. 22 p.

State and local regulatory enactments that affect private forest management are identified and summarized. The results of a Delphi technique survey of the current and long-term effects of such regulation on private timber harvests, and TAMM projections of their impact on U.S. timber supply and price, are described.
\end{abstract}

Keywords: Timber supply, state and local regulation, RPA, assessment

The United States Department of Agriculture (USDA) prohibits discrimination in its programs on the basis of race, color, national origin, sex, religion, age, disability, political beliefs and marital or familial status. (Not all prohibited bases apply to all programs.) Persons with disabilities who require alternative means for communication of program information (braille, large print, audiotape, etc.) should contact the USDA Office of Communications at (202) 720-5881 (voice) or (202) 720-7808 (TDD).

To file a complaint, write the Secretary of Agriculture, U.S. Department of Agriculture, Washington, D.C. 20250, or call (202) 720-7327 (voice) or (202) 720-1127 (TDD). USDA is an equal employment opportunity employer.

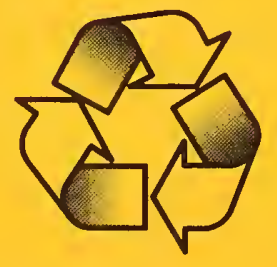

This publication was printed on recycled paper. 


\title{
The Status and Impact of State and Local Regulation on Private Timber Supply
}

\author{
John L. Greene, Research Forester \\ William C. Siegel, SupervisoryResearch Forester \\ Southern Forest Experiment Station'
}




\section{Contents}

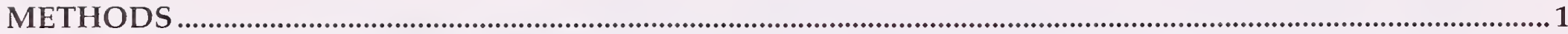

State and Local Regulatory Enactments .......................................................................................................... 1

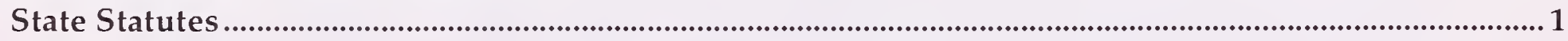

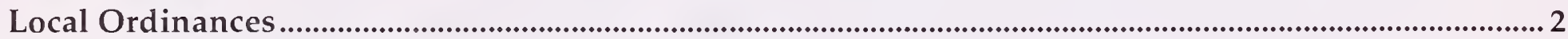

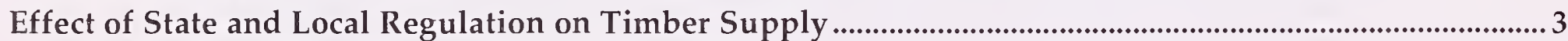

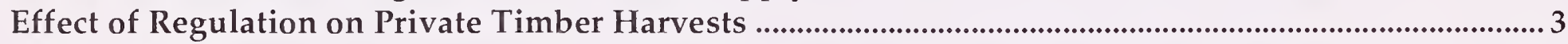

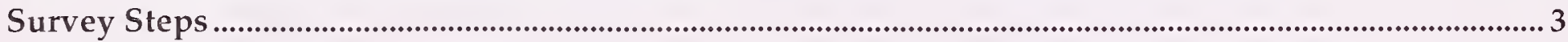

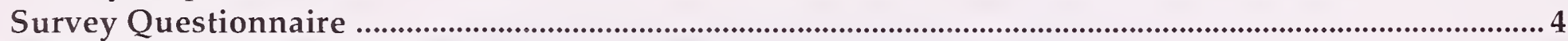

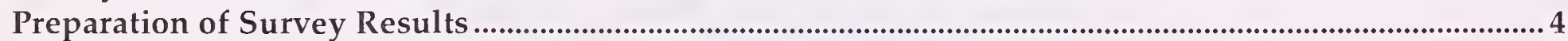

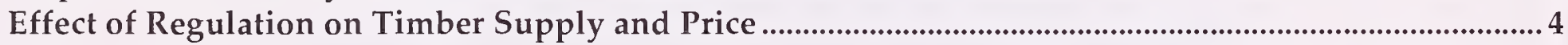

RESULTS

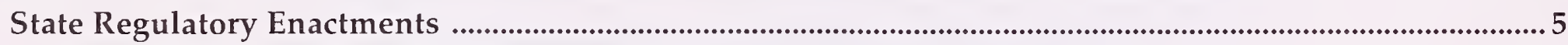

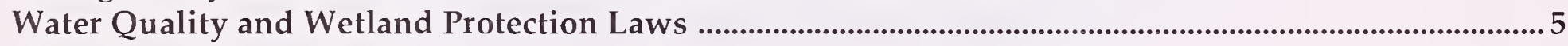

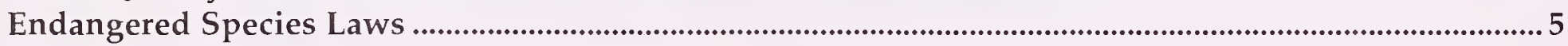

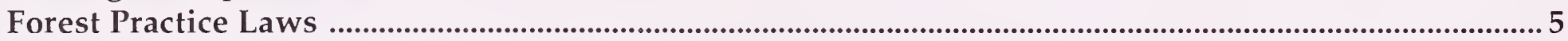

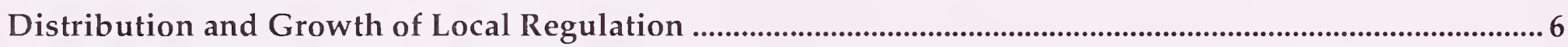

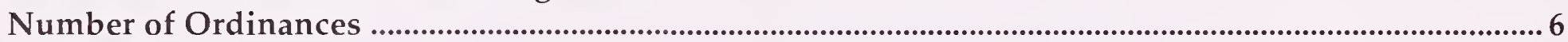

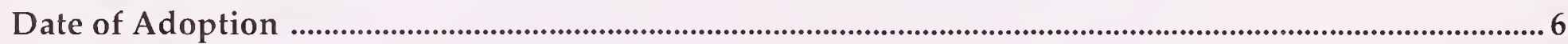

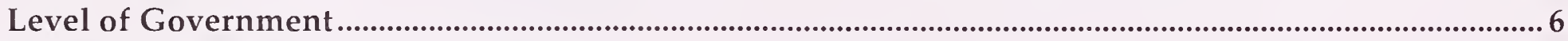

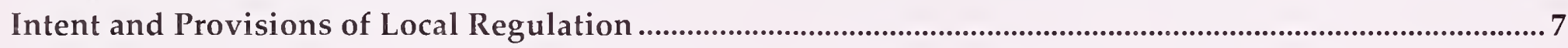

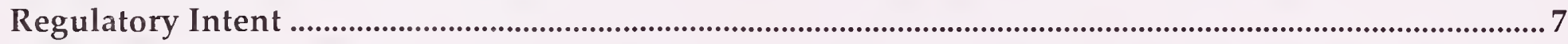

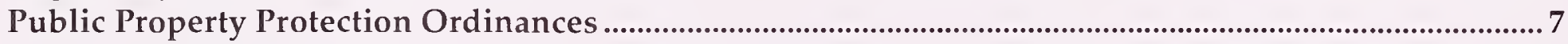

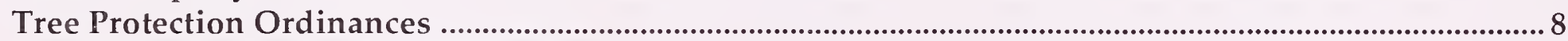

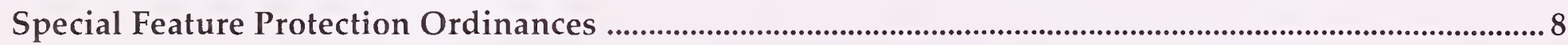

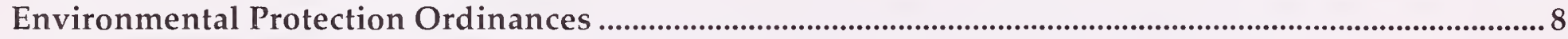

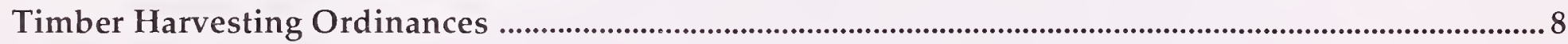

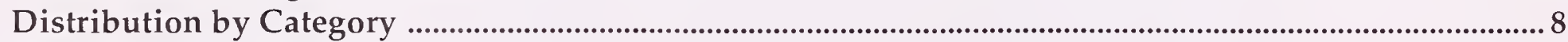

Regulatory Provisions ...............................................................................................................................................

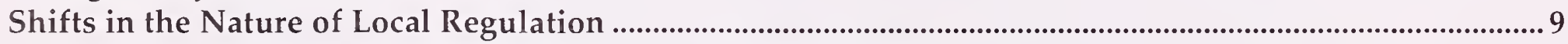

Current Effect of State and Local Regulation on Private Timber Harvests .....................................................10

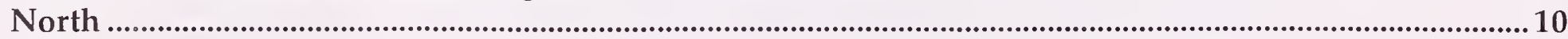

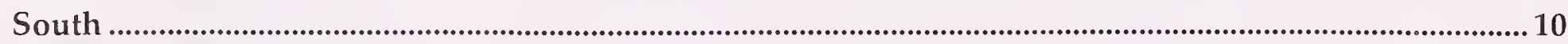

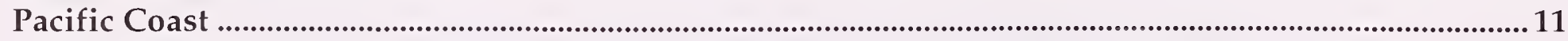

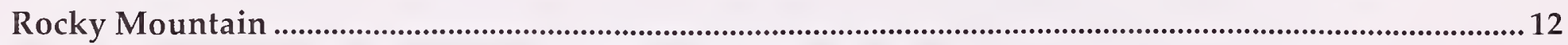

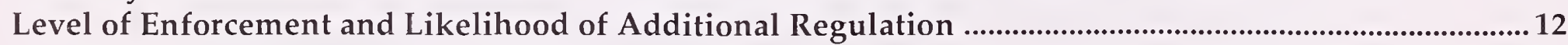

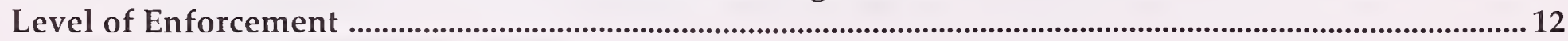

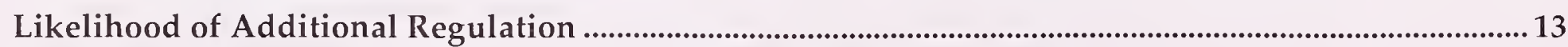

Future Effect of State and Local Regulation on Private Timber Harvests ................................................... 13

Projected Effect of State and Local Regulation on Timber Supply and Price ..................................................14

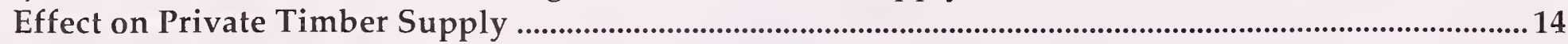

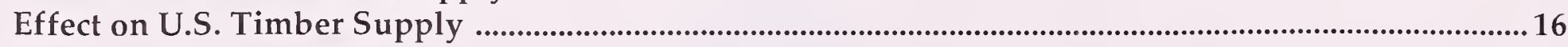

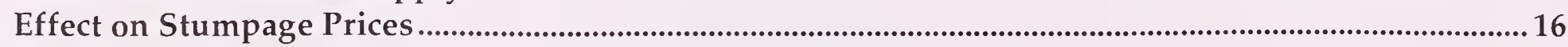

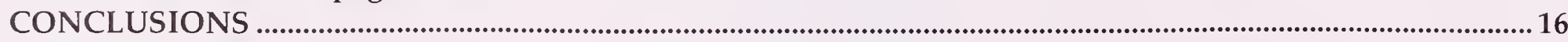

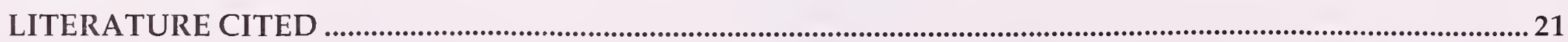




\title{
The Status and Impact of State and Local Regulation on Private Timber Supply
}

\author{
John L. Greene and William C. Siegel
}

As harvests from public forests have diminished in recent years, the market and market analysts have looked to private forest lands to provide more of the timber supply. At the same time, however, there has been an increase in state and local regulation (Hickman and Martus 1991) that directly or indirectly affects the management and productivity of private forests.

Searches conducted in 1992 identified 644 individual forest regulatory laws that had been enacted throughout the U.S. (fig. 1). Of these, 117 were at the state level, and 527 at the local level (fig. 1). State statutes include water quality, endangered species, and forest practice laws. The greatest number of state laws occurs in the North (fig. 1); but the Pacific Coast region has the longest experience with this type of regulation.

Many laws - 170 nationwide - were passed at the county level (fig. 1). Ninety percent of the county ordinances affecting private forest management were enacted in the past 10 years, and two-thirds (66\%) in the past 5 years (Martus 1992). Examples include ordinances to control erosion and stream sedimentation, and to protect county roads and bridges from damage by logging trucks. Most county-level ordinances occur in the South (fig. 1).

The remaining 357 enactments were passed at the municipal level (fig. 1; for this paper, the term "municipal" includes all units of government smaller than a county). Three-fourths of the total (76\%) date from the past 10 years, and more than half (54\%) from the past 5 years (Martus 1992). Many different types of municipal ordinances affect private forest land management. Examples include ordinances to protect shade trees and greenbelts, to prescribe silvicultural practices, and to limit hours of operation for heavy equipment. Most municipal-level ordinances occur in the North (fig. 1). County and municipal ordinances in particular tend to be passed independently, without coordination with other levels of regulation, and often without full understanding of their potential ecological and economic effects.

The objectives of this study were:

1. To identify and describe, by Resources Planning Act (RPA) region, and for the United States as a whole, the state and local regulatory enactments that affect management and productivity of private forest lands, and

2. To estimate, by RPA region, and for the United States as a whole, the current and long-term effects of such regulation on private timber harvests and on timber supply and price.

\section{METHODS}

\section{State and Local Regulatory Enactments}

Before this study, the Law and Economics research unit of the Southern Forest Experiment Station already had compiled and tabulated a considerable amount of information concerning the various state laws that affect forestry. However, very little was known about the nature and extent of local government regulation. Therefore, most of this effort focused on local government ordinances.

\section{State Statutes}

Three types of state legislation were considered in the study: water quality and wetland protection laws, endangered species laws, and forest practice laws. These account for most of the state regulatory impact on private timberlands. Existing information for these 
statutes was updated, primarily by examining state statute compilations for amendments to existing laws and for new legislative enactments. This was followed by telephone calls to knowledgeable individuals within particular states, and with a comprehensive review of existing literature on the subject.

\section{Local Ordinances}

Analysis of local regulation was complicated because local government ordinances are not systematically incorporated into any form of centralized legal or legislative reporting system. The little existing literature on local forestry regulation discussed only measures enacted within a particular state, and even then, usually in a very general way.

Local government forestry ordinances were surveyed using a variety of methods. Existing ordinances were identified by reference to published articles, and by mail and telephone inquiries. Authors who had written on the subject, state forestry agencies, state forestry associations, extension for- esters, university faculty members, loggers, industrial and consulting foresters, local government officials, and government associations were the primary sources used to compile information. Persons contacted also were asked to provide the names, addresses and telephone numbers of additional sources of information on the subject. This process was continued until all leads were exhausted.

In most cases, the contacts were able to provide only the names of local government entities that had enacted ordinances. These were contacted, either by mail or telephone, to obtain copies of the ordinances. Five items of information were tabulated for all ordinances collected: name of the government entity, legislative citation and date of adoption, purpose and intent of the ordinance, important regulatory provisions, and the named enforcement individual or agency. When possible, information also was obtained on how strictly the ordinance was being enforced by local officials. These data were analyzed in terms of type of ordinance, regional differences, legislative history, and national and regional trends.
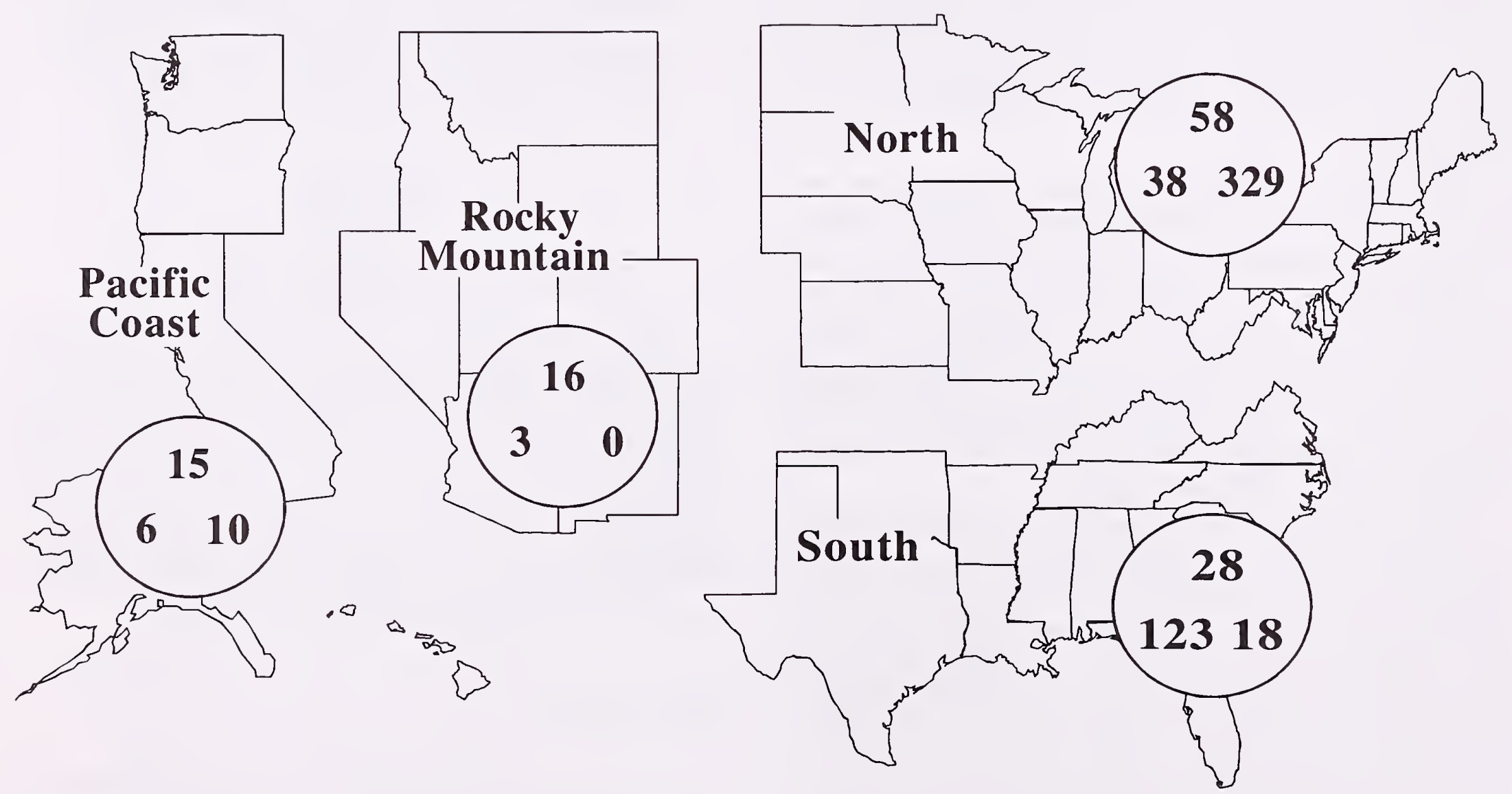

KEY: Top Number $=$ Number of state laws in the region that affect management of privately owned forest lands. Lower Left Number $=\ldots . .$. Number of county ordinances in the region that affect management of privately owned forest lands. Lower Right Number $=\ldots$... Number of municipal ordinances in the region that affect management of privately owned forest lands.

Figure 1.-State and local regulation in the United States, by RPA region. 


\section{Effect of State and Local Regulation on Timber Supply}

\section{Effect of Regulation on Private Timber Harvests}

The effect of state and local regulation on private timber harvests was estimated using the Delphi procedure. The procedure was developed by the Rand Corporation, in the 1950 s, to solve complex planning problems in engineering and defense. It is a systematic process for combining the knowledge and judgement of a small number of experts in a given field. It is well suited to studies such as this one, where a mathematical model would require too many assumptions to provide meaningful results (Gregersen et al. 1989).

The Delphi procedure has been used to investigate various natural resource topics, including future leisure environments (Shafer et al. 1974), elk habitat quality (Schuster et al. 1985), and state forest policy alternatives (Baughman and Ellefson 1983, Henderson et al. 1992). In the technique, researchers prepare a questionnaire and submit it to selected experts. The results are summarized and returned to the experts, who are given an opportunity to revise their answers. The procedure often is ended at that point; but the summarization and revision steps can be repeated until a desired level of consensus is reached (Gregersen et al. 1989).

\section{Survey Steps}

We considered a sample size of approximately 80 as large enough to provide reliable results at the regional level while still being manageable. Starting from an initial design of one respondent per state, we added one respondent each for states with more than $5 \%$ of all private forest land in the United States, and one each for states with more than $5 \%$ of the state and local enactments identified in the first part of the study (Martus 1992). We eliminated from the sample five states with little private forest land compared with others in their region, and with no county or municipal regulation affecting private forests: Alaska, Delaware, North Dakota, Rhode Island, and Wyoming.

To identify the most qualified individuals to participate in the study, we conducted a presurvey of persons in each state to be sampled. Some of the persons contacted had cooperated in the first part of the study (Martus 1992); the others were affiliated with state agencies and associations identified in the National Wildlife Federation Conservation Directory (1992). After contacting them, we described the purpose of the study and asked them to name the individual or individuals best qualified to respond for their state and region. To the extent possible, the individuals selected to participate in the study were recommended by two or more persons. Many were named by persons in states throughout their region.

The first step of the Delphi survey was conducted during summer 1992. The selected individuals were contacted by mail at least 1 week before survey calls began in their region. The letter introduced the study, invited them to participate, and emphasized the importance of their response in this small-sample procedure. Then, in telephone calls, the respondents were guided through the questionnaire described later and were asked to answer the questions based on their individual knowledge and experience. The results were coded by region; and the high, low, and median responses for each question were determined.

During the first survey step, it was necessary to make minor adjustments to the sample. A few of the invitees were unable or declined to participate in the study, and were replaced in the sample by alternates selected from a prepared list. In addition, the sample size was increased to 83 , to obtain at least three responses for each state.

Table 1 shows the final sample, by region and respondent occupation. The number of respondents per region averaged 21, but varied according to the number of states, the number of private forest land acres, and the number of state and local enactments (table 1a). Respondent occupations were nearly evenly divided between the public and private sectors (53\% versus $47 \%$, respectively; table $1 \mathrm{~b}$ ).

The second step in the Delphi survey was conducted during fall 1992. The original respondents were contacted and guided through the questionnaire a second time. At each question, they were reminded of their original answers, were provided with the high, low and median responses, then were given an opportunity to revise their answers. Second-step interviews were completed with 81 of the 83 respondents. In the two missing cases, we kept the respondents' answers from the first survey step in the final data set, rather than lose the information. 


\section{Survey Questionnaire}

The questionnaire consisted of four parallel series of questions, one each on state water quality regulation, state endangered species regulation, state forest practice regulation, and county and municipal regulation. In each series, we asked the respondents whether regulation of that type currently had any noticeable effect_-either positive or negative_-on timber harvests from private forest lands, in states in their region. If they answered "yes," we asked them to describe the nature of the effect and estimate its extent.

Then we asked the respondents whether they expected regulation to have any additional effect on private timber harvests — positive or negativeover the next 10 years. Again, if they answered "yes," we asked them to describe the nature of the anticipated effect and estimate its extent. Next, we asked them to estimate how fully the existing regulation was being enforced and whether they expected that to change in the foreseeable future. Finally, we asked them to estimate the likelihood that additional regulation would be passed in the foreseeable future, and to predict its time frame and nature.

For each question, we collected responses by ownership class (forest industry or nonindustrial private) and by species and product group (hardwood pulpwood, hardwood sawtimber, softwood pulpwood, and softwood sawtimber). After a questionnaire was completed, we summed the estimates for

Table 1.-Number of respondents in the study sample, by geographic region and occupation.

Number of respondents

a. By Geographic Region

North …............................................................. 36

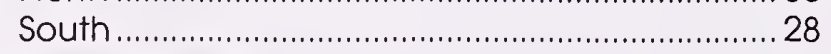

Pacific Coast ....................................................... 10

Rocky Mountain ...................................................... 9

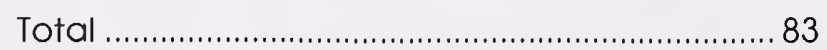

b. By Occupation

Public agency ........................................................ 31

Academic/Extension ......................................... 13

Consulting forester .............................................. 14

Forest industry .................................................... 12

Association ......................................................... 10

Forest land owner ........................................... 3

Total .............................................................. 83 current and anticipated future effects, and asked the respondent whether the totals were what he or she intended. If they were not, we asked the respondent to help us to adjust the answers.

\section{Preparation of Survey Results}

As is typical in a policy-oriented Delphi study, the second survey step narrowed the range between the high and low responses for each question, but did not produce full consensus. This was particularly the case for questions requiring the respondents to predict a future condition. The findings reported and discussed in the results section are the median response for each question in each region. They were calculated by weighting the median responses for each state by the estimated harvest of each species and product group from each forest ownership class (Waddell et al. 1989), then summing them to yield regional totals.

\section{Effect of Regulation on Timber Supply and Price}

The median Delphi survey results were submitted to the USDA Forest Service Pacific Northwest Forest and Range Research Station, where they were used to help formulate alternative future scenarios in the Timber Assessment Marketing Model (TAMM) to project the effect of state and local regulation on future timber supply and stumpage prices. Station scientists returned three separate projections for the years 1990 through 2040:

A baseline projection, which did not include an effect of regulation, for comparison with the other projections;

A current effect projection, which used the Delphi estimates of the effect of regulation at the time the survey was done;

A future effect projection, which used the Delphi estimates of the additional effect of regulation anticipated over the next 10 years.

Output was provided at 10-year intervals through the end of the projection period. It included private timber harvests, by region, ownership class, species, and product group; U.S. sawtimber harvests, by region and species group; and average sawtimber stumpage prices, by region, and species group. 
The harvest and stumpage price figures for the year 1990 were historical, and were the same for all three projections. Three assumptions were made in determining the figures to use for the years 2000 through 2040: (1) the current effect of regulation observed by the respondents represents a change since the 1990 base year, (2) the change from current to anticipated future effect will take place uniformly over time, and (3) the future effect will be fully realized within 10 years (i.e., by the year 2003).

In accordance with the assumptions, the figures reported and discussed here, for years 2010 through 2040 , were taken from the future effect projection. ${ }^{2}$ The figures used for 2000 required an adjusting calculation, because that year is between the time of the survey and the time the future effect was assumed to be fully realized. The adjustment was made by adding to each value in the current effect projection, $70 \%$ of the difference between it and the analogous value from the future effect projection.

\section{RESULTS}

\section{State Regulatory Enactments}

\section{Water Quality and Wetland Protection Laws}

State water quality laws that potentially can affect forestry operations were inventoried by Siegel and Haines as part of the 1989 Resources Planning Act (RPA) Water Assessment (Guldin 1988). This review showed that all 50 states have some type of general water quality legislation. A few of these statutes were enacted before 1972, but most are traceable to the requirements of the Federal Water Pollution Control Act Amendments passed in that year.

The state laws differ substantially in their specific provisions, but all are broad in scope. Even in those cases where silvicultural activities are not specifically mentioned in the statute as a possible source of pollution, forestry operations, by implication, could be covered. Nevertheless, most states continue to rely on voluntary means of controlling forestry nonpoint pollution. Only about one-fourth have enacted forestry-specific water quality-related regulatory legislation. Generally, in states that operate

\footnotetext{
${ }^{2}$ This report discusses the differences between the baseline projection and the projections of the effect of state and local regulation. The baseline projection itself is discussed in another RPA update document.
}

within a voluntary framework, the broad water quality laws have been applied to silvicultural operations only on a limited basis. In some states, however, they are beginning to be invoked more regularly.

All coastal states, including those bordering the Great Lakes, exercise some type of regulatory control over the development of wetlands within their coastal zones. Each of these statutes addresses silvicultural operations. The protection of interior freshwater wetlands is much less extensive, but is increasing in scope. About one-third of the states have comprehensive interior wetland protection laws that govern forestry activities within wetland zones.

\section{Endangered Species Laws}

All but six states have some type of endangered species law. Those without such legislation are Alabama, Arkansas, Massachusetts, North Dakota, Rhode Island, and West Virginia.

The relationship between the federal Endangered Species Act and state endangered species protection programs occurs in three areas: state-federal cooperative agreements, state endangered species laws, and state forest practice regulatory statutes. Federal law generally preempts state law. In states with cooperative agreements, however, the federal taking provision is enforceable only to the extent that taking is defined in the state law. In such cases, a federal taking violation requires a violation of state law (Quarles et al. 1991).

Not all of the interactions between federal and state legislation have been clearly defined. For example, not all state laws define a taking to include adverse habitat modification, as does the federal law. Several states with comprehensive forest practice regulatory legislation have included endangered species provisions in the statutes.

\section{Forest Practice Laws}

Currently, 21 states have formal forest practice regulatory legislation. They are Connecticut, Delaware, Maine, Maryland, Massachusetts, Missouri, New Hampshire, New York, and Vermont in the North RPA region; Florida, Louisiana, Mississippi, Virginia, and West Virginia in the South; Alaska, California, Oregon, and Washington in the Pacific Coast region; and Idaho, 
Nevada, and New Mexico in the Rocky Mountain region. Only 10 of these laws can be termed comprehensive statutes, however (Siegel 1990). As the listing indicates, the laws are most prevalent in the North and Pacific Coast regions. ${ }^{3}$

\section{Distribution and Growth of Local Regulation}

\section{Number of Ordinances}

The survey of local ordinances identified 527 individual forest-related ordinances that had been enacted by 493 separate units of local government in 24 states (table 2). A forest-related ordinance was defined as any ordinance, zoning law, or tree protection article which has been or could be used to restrict silvicultural or logging activities, or the hauling of forest products. Local government refers to any level of government below the state level. Included are counties, townships, municipalities, villages and boroughs.

Of the 493 local governments identified as having enacted forest-related ordinances, 460 had passed a singleordinance. Thirty-two local governmental units in eight states had enacted two ordinances each, and one unit had enacted three (table 3). The largest number of ordinances was found in the northeast, which accounted for more than two-thirds $(68 \%)$ of all ordinances. The southeast followed, with onefifth $(21 \%)$ of the total (table 3$)$.

\section{Date of Adoption}

A small fraction of the ordinances identified (5\%) had no identifiable date of adoption. Of the others, nearly four-fifths (78\%) had been enacted in the past 10 years, and fully half ( $50 \%$ ) had been adopted in the past 5 years (table 4 ).

\section{Level of Government}

The number of forestry ordinances enacted in various regions of the country is associated with the level of local authority or "home rule." Possessing

\footnotetext{
${ }^{3}$ A more detailed discussion of state forest practice regulation can be found in Siegel, W.C. 1990. Legislative Regulation of Private Forestry Practices in the United States-Recent Developments. In: Forestry Legislation, Report of IUFRO Working Party S4.08-03, Zurich, Switzerland, p. 349-364.
}

Table 2.-Number of forest-related ordinances enacted in the United States, by RPA region and state.

Region and State

Number of ordinances

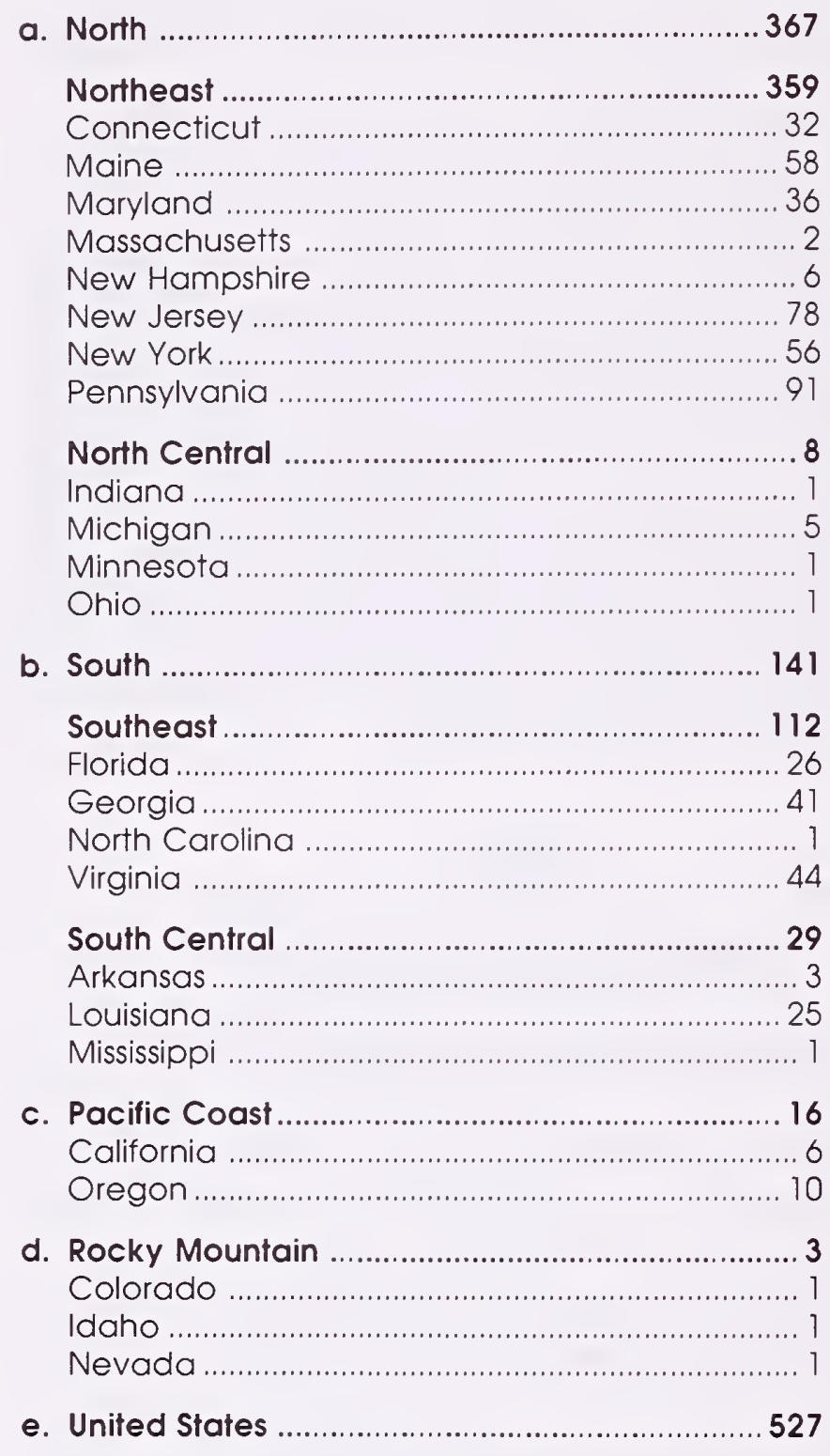

the authority to act is a requisite condition for any government wishing to control forestry activities. Levels of local autonomy differ drastically among states and regions. Each state has a unique relationship with its local governments.

The statewide forest practice regulatory acts enacted by most of the forested states in the Pacific Coast and Rocky Mountain regions restrict the ability of local governments to pass independent ordinances regulating forest activities. The north central states also generally limit local government autonomy in this area. Thus, few forest-related ordinances have been enacted in western or north central states (table 3). 
Local governments in the northeast traditionally have exhibited a greater degree of local autonomy than those in other regions, primarily because of greater constitutional and statutory grants of authority than elsewhere. This is one reason for the large number of forestry ordinances found in northeast states. Another is the traditional structure of local government in the region. Townships, towns, villages, boroughs and municipalities serve as the fundamental form of local government, with counties usually providing only an auxiliary function. Of the 359 local units of government in the northeast identified as having forest-related ordinances, $90 \%$ were at less than the county level (table 3 ).

In contrast, the county is the prevalent unit of local government in the South. Nearly 9 of every 10 ordinances $(87 \%)$ in the South were enacted at the county level (table 3).

\section{Intent and Provisions of Local Regulation}

\section{Regulatory Intent}

The local government ordinances identified in this study can be distinguished largely by their regulatory intent. Most contain an introductory statement that outlines the purposes for enactment. These statements provide insight into the attitudes and motivations of the governmental unit and its citizens.

The legislative intent of ordinances differs dramatically in scope among states and regions. Most ordinances have several stated objectives. Each ordi-

Table 3.-Level of local government enacting forest-related ordinances, and number of local governments enacting one, two, and three ordinances, by RPA region.

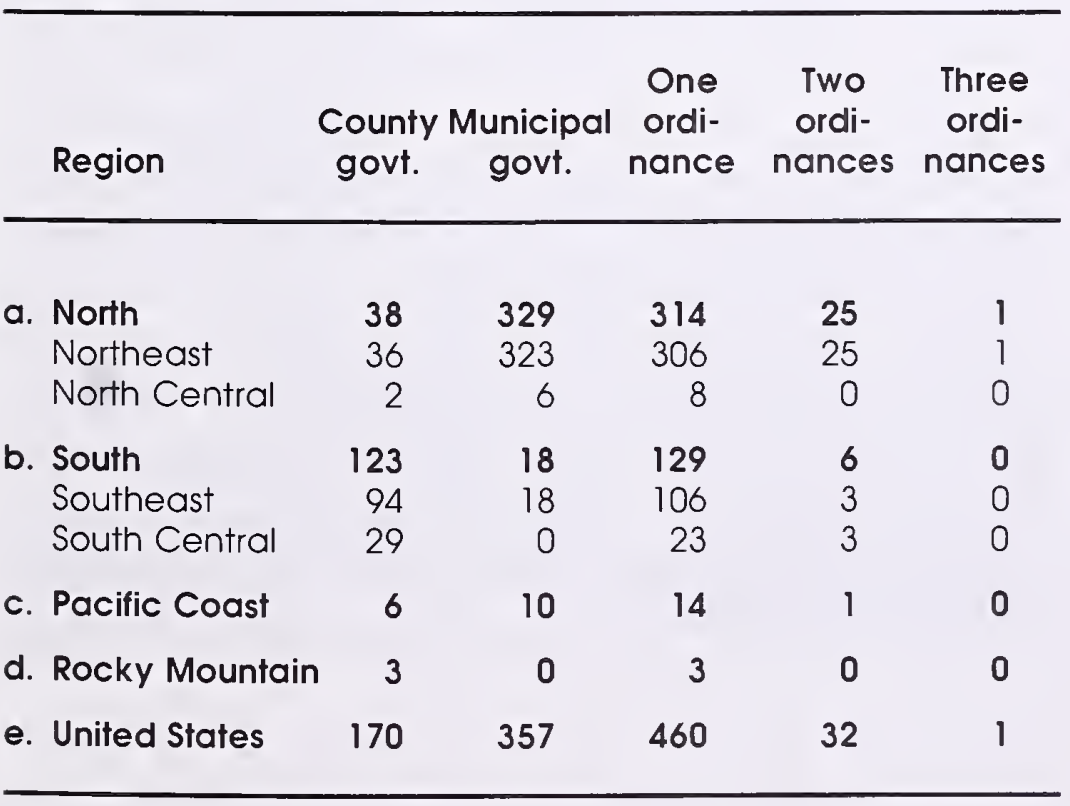

Table 4.-Number of forest-related ordinances enacted in the United States, by objective, time adopted, and RPA region.

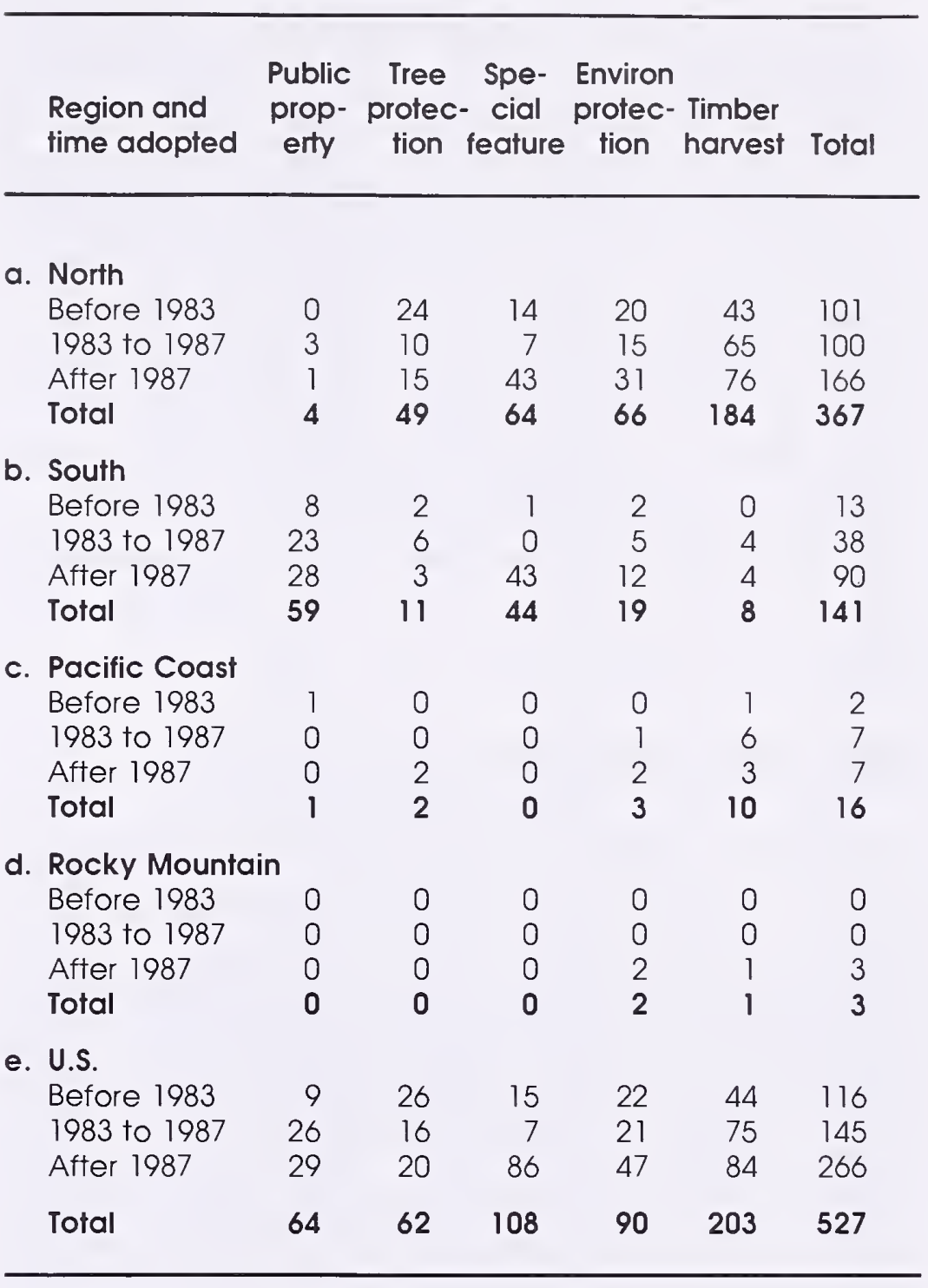

nance, however, can be placed into one of five categories, according to its primary objective. The categories are: public property protection, tree protection, special feature protection, environmental protection, and timber harvesting.

\section{Public Property Protection Ordinances}

These ordinances generally are enacted to protect the local government's investment in roads, bridges, ditches, and rights-of-way, by placing restrictions on the use of logging vehicles and machinery. A common secondary objective is to protect motorists from potentially hazardous driving conditions. Typical provisions include harvesting permits and plans, mandatory inspections of operations, removal of mud and debris from roads and ditches, the use of gravel mats at entrances to public roads, and restrictions against use of roads during stated hours and weather conditions. 


\section{Tree Protection Ordinances}

These ordinances are associated primarily with the preservation of trees and wooded areas in urban and suburban settings. They govern the removal of one or more trees on private land. Unlike timber harvesting ordinances, tree protection ordinances generally have not been enacted to regulate commercial forestry operations per se. Rather, they have been adopted generally to regulate tree removals associated with land clearing and development activities. They affect commercial timber harvests by restricting the removal of large groups of forest trees for any purpose within the regulated area. Common provisions include harvesting permits, site plans, and replanting requirements.

\section{Special Feature Protection Ordinances}

These are ordinances enacted for the specific purpose of protecting designated areas because of their scenic or environmental value. The ord inances rarely encompass all forest areas within a local government's jurisdiction. Examples of designated protection zones include scenic river corridors, shoreline and coastal areas, recreational districts, viewsheds, and critical habitat areas for threatened and endangered species. Common requirements include harvest permits, management plans, and leaving buffer zones. Many special feature protection ordinances limit the volume of timber that can be removed from a regulated area, while others prohibit forestry activities altogether.

A recent regulatory trend has resulted in the enactment of many special feature protection ordinances in the states of Maine (24 ordinances), Maryland (13 ordinances), and Virginia (40 ordinances) in the past 5 years. The state governments in these three states have passed laws that establish minimum standards and mandate that local units of government enact ordinances to protect environmental features that are either of great size or common to many local governments - the Chesapeake Bay in Maryland and Virginia, and inland freshwater shorelands in Maine.

\section{Environmental Protection Ordinances}

The primary intent of these ordinances is to protect the general environment from "land disturbing activities." Most are zoning codes, or ordinances primarily intended to control stormwater drainage or erosion and sedimentation. However, their wording is such that silvicultural operations, timber removal, and forest road construction qualify as regulated activities. Harvest permits, erosion control plans, leaving buffer zones, and restrictions on harvest methods are common regulatory provisions. This type of ordinance also is used to regulate the use of prescribed burning and herbicides.

\section{Timber Harvesting Ordinances}

These ordinances were enacted to directly regulate silvicultural and timber harvesting operations. Their stated purpose generally is to limit site degradation and environmental damage associated with commercial forestry activities. Protection of forest resources, and conservation of esthetic values and wild life habitat, were two primary reasons stated by the governments enacting this type of law. Common requirements include timber harvesting permits, harvest and management plans, leaving buffer zones, restrictions on silvicultural practices, and standards for road construction and maintenance. Both timber harvesting and environmental protection ordinances often include provisions to waive requirements if operations are supervised by a professional forester or done under a management plan approved by the state forestry agency.

\section{Distribution by Category}

Timber harvesting ordinances were the most numerous of the five categories, accounting for $39 \%$ of all local ordinances (table 4). Special feature and environmental protection ordinances each represented about one-fifth of the total (20\% and $17 \%$, respectively). The remaining one-fifth was evenly divided between public property and tree protection ordinances ( $12 \%$ each, table 4 ).

The northeast states dominated the count in all categories of ordinances except public property protection. More than nine-tenths (92\%) of public property ordinances were enacted by local governments in the South RPA region; only a few (5\%) were found in the North (table 4). 


\section{Regulatory Provisions}

Together, northeast states and the South accounted for nearly all (95\%) local forest-related ordinances. Analysis of the ordinances in these areas identified nine regulatory provisions that were used with at least moderate frequency, and an additional five provisions that were somewhat less common.

Harvest or Haul Permits.-Two-thirds (69\%) of local ordinances in the northeast states and one-third (34\%) in the South required permits to harvest or haul timber products. Permit fees typically ranged between $\$ 10$ and $\$ 50$, but occasionally exceed $\$ 100$ in the South. Some harvest permit fees in northeast states are based on the number of acres harvested; in the South, a few ordinances set haul permit fees according to the distance traveled on county roads.

Forest Management Plans.- Just under two-thirds $(62 \%)$ of ordinances in northeast states and oneseventh $(14 \%)$ in the South require that forestry activities be carried out under the provisions of a written forest management plan prepared by a professional consulting forester. Some also require that biologists, hydrologists, or archaeologists participate in the review process.

Buffer Zones.-Buffer zone requirements were found in about two-fifths ( $43 \%$ ) of local ordinances in northeast states and one-tenth (9\%) in the South. Buffers are most commonly required along watercourses, property lines, roads, and drainage facilities. The required buffer width ranges from 15 to 150 feet. In most cases, buffers must be left in their natural state. Some ordinances, however, allow limited harvesting.

Best Management Practices.-Two-fifths (38\%) of local ordinances in the South and nearly one-tenth $(7 \%)$ in northeast states required forest operators to adhere to voluntary state Best Management Practices (BMPs). BMPs usually are adopted to minimize erosion and sedimentation associated with forest roads and harvesting and skidding timber. Common provisions include specifications for waterbars and residual forest stocking, protection of streamside management zones, and reseeding roads after a harvest.
Performance Bonds.-Approximately one-third $(35 \%)$ of local ordinances in northeast states and onefifth $(21 \%)$ in the South required loggers or timber haulers to provide surety bonds, performance bonds, or irrevocable letters of credit. Although extremely large bonds are mandated in some instances, most ranged from $\$ 200$ to $\$ 5,000$.

Bridges and Culverts.-One-third (34\%) of ordinances in northeast states and one-fifth $(18 \%)$ in the South stipulate that bridges and culverts must be used for stream crossings. Typically, the bridges and culverts are to be removed after harvest, and the site must be restored to its original condition.

Logging Slash Reduction.-Nearly one-third (31\%) of the ordinances in northeast states contained logging slash and debris provisions. Most specify that logging slash can be placed no closer than 50 feet from any watercourse, road, or property line, and can be no more than 4 feet high.

Harvests by the Selection Method.-One-fourth $(25 \%)$ of local ordinances identified in northeast states limit timber harvests to the selection method. Most such ordinances expressly prohibit clearcutting. Definitions of clearcutting vary widely, but in most cases openings are not to exceed one-fifth acre in size. Other related provisions often found in these ordinances require fixed percentages of residual forest stock to be maintained after a harvest.

Debris-Clearing Requirements.-One-fourth ( $24 \%$ ) of the ordinances identified in the South require forest operators to clear mud and logging debris from public roads and drainage facilities.

Less commonly used in forest-related ordinances in northeast states and South were requirements to notify local officials before harvesting or hauling timber, to install gravel pads and culverts at entrances to public roads, to discontinue hauling operations on given days, at given times, or under given weather conditions, and to hold a public hearing before being granted a harvest permit.

\section{Shifts in the Nature of Local Regulation}

The past 10 years also have seen a significant change in the type of forest-related ordinances that 
local governments enact. There has been a shift away from public property and tree protection ordinances, which have a relatively minor impact on private timber harvests, toward special feature protection, environmental protection, and timber harvesting ordinances, which have a greater impact.

The shift is most noticeable in the North RPA region, where the proportion of ordinances in the last three categories grew from three-fourths (76\%) among ordinances enacted before 1983, to nine-tenths (90\%) among ordinances enacted after 1987 (table 4). However, it also is occurring in the South, where the proportion in the last three categories increased from one-fourth (23\%) among ordinances enacted before 1983, to two-thirds (66\%) among ordinances enacted after 1987 (table 4).

\section{Current Effect of State and Local Regulation on Private Timber Harvests}

\section{North}

Respondents to the Delphi procedure survey estimated that, in the North RPA region, state water quality regulation currently causes a $1 \%$ reduction in private harvests of hardwood timber products and a $1 \%$ to $2 \%$ reduction in harvests of softwood products (table 5). State endangered species regulation was estimated to cause an additional $1 \%$ reduction in harvests of hardwood sawtimber, but appeared to have no effect on harvests of other products (table 5).

The respondents credited the reforestation requiręments of some state forest practice acts in the region with increasing timber harvests from nonindustrial private lands by $2 \%$ for hardwood products and $1 \%$ for softwood. However, these increases were at least partially offset by reductions in harvests from forest industry land. The net result was an estimated $2 \%$ increase in hardwood product harvests, and no change in softwood product harvests (table 5). County and municipal regulation was estimated to cause an additional $1 \%$ reduction in harvests of all types of timber products (table 5).

State endangered species regulation and county and municipal regulation appeared to have a greater effect on nonindustrial private than forest industry lands (table 5). Respondent comments during the survey indicated this is because nonindustrial holdings tend to be located closer to population centers
Table 5.-Median estimates of the current effect (in percent change) of state and local regulation on private timber harvests in the North, by type of regulation, species and product group, and ownership class.

All private Forest Nonindustrial forest lands industry private

\begin{tabular}{lccc} 
a. State Water Quality Regulation & & & \\
Hardwood Pulpwood & -1 & -1 & -1 \\
Hardwood Sawtimber & -1 & -1 & -1 \\
Softwood Pulpwood & -1 & -1 & -1 \\
Softwood Sawtimber & -2 & -2 & -2 \\
b. State Endangered Species Regulation & & \\
Hardwood Pulpwood & 0 & 0 & 0 \\
Hardwood Sawtimber & -1 & 0 & -1 \\
Softwood Pulpwood & 0 & 0 & 0 \\
Softwood Sawtimber & 0 & 0 & 0 \\
c. State Forest Practice Regulation & & & \\
Hardwood Pulpwood & +2 & -1 & +2 \\
Hardwood Sawtimber & +2 & 0 & +2 \\
Softwood Pulpwood & 0 & -3 & +1 \\
Softwood Sawtimber & 0 & -3 & +1 \\
d. County and Municipal Regulation & & \\
Hardwood Pulpwood & -1 & -1 & -1 \\
Hardwood Sawtimber & -1 & -1 & -1 \\
Softwood Pulpwood & -1 & -1 & -1 \\
Softwood Sawtimber & -1 & -1 & -2 \\
e. Total Effect & & & \\
Hardwood Pulpwood & -1 & -2 & -1 \\
Hardwood Sawtimber & -1 & -3 & -1 \\
Softwood Pulpwood & -3 & -5 & -2 \\
Softwood Sawtimber & -3 & -6 & -3 \\
& & & \\
\hline
\end{tabular}

Note: Figures may not sum to total because of rounding.

than industry land, and because nonindustrial owners are more likely to abandon a timber sale out of frustration over regulatory processes.

The net effect of state and local regulation on current private timber harvests in the North was an estimated $1 \%$ reduction in harvests of hardwood products, and a $2 \%$ reduction in harvests of softwood products (table 5). As might be expected, the survey results indicated that most of the effect occurs in northeast states, where regulation is concentrated.

\section{South}

Survey respondents in the South RPA region estimated that state water quality regulation currently causes a $1 \%$ reduction in private harvests of both hardwood and softwood timber products (table 6). State endangered species regulation was estimated 
to reduce harvests of softwood products by an additional $1 \%$, but appeared to have little effect on hardwood product harvests (table 6). Respondent comments indicated that most of the effect of endangered species regulation results from uncertainty; forest owners are hesitant to conduct forest practices because they don't want to risk breaking a law.

The respondents saw no current effect on private timber harvests from state forest practice regulation (table 6). They estimated that county and municipal regulation causes a uniform $1 \%$ reduction in harvests of all products (table 6).

In this region, state and local regulation appeared to affect forest industry holdings more than nonindustrial private (table 6). Respondents suggested this is because industry holdings are large and easy to identify, and because firms have a substantial stake in the success of voluntary BMP programs, so they ensure they are in compliance.

Table 6.- Median estimates (in percent change) of the current effect of state and local regulation on private timber harvests in the South, by type of regulation, species and product group, and ownership class.

All private Forest Nonindustrial forest lands industry private

\section{a. State Water Quality Regulation}

Hardwood Pulpwood -

Hardwood Sawtimber

Softwood Pulpwood

Softwood Sawtimber

b. State Endangered Species Regulation

Hardwood Pulpwood Hardwood Sawtimber

Softwood Pulpwood

Softwood Sawtimber

c. State Forest Practice Regulation

Hardwood Pulpwood 0

Hardwood Sawtimber

Softwood Pulpwood

Softwood Sawtimber

0

0

0

d. County and Municipal Regulation Hardwood Pulpwood Hardwood Sawtimber Softwood Pulpwood Softwood Sawtimber

e. Total Effect

Hardwood Pulpwood Hardwood Sawtimber Softwood Pulpwood Softwood Sawtimber

Note: Figures may not sum to total because of rounding.
The combined effect of state and local regulation in the South was an estimated 3\% reduction in harvests of all timber products (table 6). Survey results indicated that the effect of state water quality regulation is concentrated in southeast states, while the effect of state endangered species regulation is concentrated in the south central states.

\section{Pacific Coast}

The survey results clearly indicated that state and local regulation has its greatest impact on private timber harvests in the Pacific Coast region. State water quality regulation was estimated to reduce current harvests of hardwood and softwood pulpwood by $2 \%$, hardwood sawtimber by $3 \%$, and softwood sawtimber by $4 \%$ (table 7 ). State endangered species regulation was estimated to reduce harvests of hardwood products by $1 \%$ or less, softwood pulpwood by $2 \%$, and softwood saw timber by $6 \%$ (table 7 ). State forest practice regulation was estimated to reduce harvests of hardwood and softwood pulpwood by $2 \%$, hardwood sawtimber by $3 \%$, and softwood sawtimber by $2 \%$ (table 7 ).

In most Pacific Coast states, the forest-related water quality and endangered species regulations are included in the state forest practice act. To avoid doublecounting, we asked respondents in the region to focus on the effects of the water quality and endangered species sections of the acts as we covered them in the questionnaire, and to factor those effects out of their responses for forest practice regulation. The results for the three types of state regulation followed a similar pattern. All indicated that nonindustrial private lands are more affected than forest industry by the aspects of state regulation that restrict harvests of softwood sawtimber (table 7).

There was no observed effect on private timber harvests as a result of county and municipal regulation (table 7). Respondent comments during the interviews indicated this is because the comprehensive state acts common to the region restrict the ability of counties and municipalities to pass independent enactments.

The combined effect of state and local regulation on current private timber harvests in the Pacific Coast region was an estimated $4 \%$ reduction in hardwood pulpwood harvests, a 7\% reduction in hardwood sawtimber harvests, a $6 \%$ reduction in softwood pulpwood harvests, and a $12 \%$ reduction in softwood sawtimber harvests (table 7). 


\section{Rocky Mountain}

Respondents in the Rocky Mountain region estimated that state water quality regulation currently has no effect on private harvests of hardwood products, but reduces softwood pulpwood harvests by $1 \%$ and softwood sawtimber harvests by $3 \%$. The effect is concentrated on forest industry lands (table 8). The respondents observed no effect on timber harvests from state endangered species regulation or forest practice regulation (table 8). However, they estimated that county and municipal regulation causes a $2 \%$ to $3 \%$ reduction in harvests of hardwood products, with the effect focused entirely on nonindustrial private holdings near urban areas (table 8).

In all, state and local regulation was estimated to cause a 3\% reduction in current private harvests of hardwood pulpwood in the Rocky Mountain region, a $2 \%$ reduction in hardwood sawtimber harvests, a

Table 7.-Median estimates of the current effect (in percent change) of state and local regulation on private timber harvests in the Pacific Coast region, by type of regulation, species and product group, and ownership class.

All private Forest Nonindustrial forestlands industry private

a. State Water Quality Regulation Hardwood Pulpwood -2 Hardwood Sawtimber $\quad-3$ Softwood Pulpwood Softwood Sawtimber

-3
-2

\section{$-2$}

$-3$

$-2$

$-4$

b. State Endangered Species Regulation

Hardwood Pulpwood

Hardwood Sawtimber

Softwood Pulpwood

Softwood Sawtimber

0
-1
-2
-6

c. State Forest Practice Regulation

Hardwood Pulpwood

Hardwood Sawtimber

Softwood Pulpwood

Softwood Sawtimber

-2
-3
-2
-2

d. County and Municipal Regulation

Hardwood Pulpwood

Hardwood Sawtimber

Softwood Pulpwood

Softwood Sawtimber

0
0
0
0

e. Total Effect

Hardwood Pulpwood

Hardwood Sawtimber

Softwood Pulpwood

Softwood Sawtimber

-4
-7
-6
-12

Note: Figures may not sum to total because of rounding.

$-1$ $-3$ $-1$ $-5$

Table 8.-Median estimates of the current effect (in percent change) of state and local regulation on private timber harvests in the Rocky Mountain region, by type of regulation, species and product group, and ownership class.

All private Forest Nonindustrial forest lands industry private

a. State Water Quality Regulation Hardwood Pulpwood Hardwood Sawtimber 0 Softwood Pulpwood Softwood Sawtimber $0 \quad 0$ $\begin{array}{rrr}0 & 0 & 0\end{array}$

State Endangered Species Regulation

Hardwood Pulpwood 0 Hardwood Sawtimber Softwood Pulpwood Softwood Sawtimber

$\begin{array}{lll}0 & 0 & 0 \\ 0 & 0 & 0 \\ 0 & 0 & 0 \\ 0 & 0 & 0\end{array}$

c. State Forest Practice Regulation Hardwood Pulpwood 0 Hardwood Sawtimber Softwood Pulpwood Softwood Sawtimber 0
0
0 0
0
0 $0 \quad 0$ $0 \quad 0$ County and Municipal Regulation Hardwood Pulpwood -3 Hardwood Sawtimber $\quad-2$ Softwood Pulpwood Softwood Sawtimber $0 \quad-3$ 0

e. Total Effect

Hardwood Pulpwood $\quad-3 \quad 0 \quad-3$ Hardwood Sawtimber $\quad-2 \quad 0 \quad-2$ Softwood Pulpwood Softwood Sawtimber

Note: Figures may not sum to total because of rounding.

$1 \%$ reduction in softwood pulpwood harvests, and a $3 \%$ reduction in softwood sawtimber harvests (table 8).

\section{Level of Enforcement and Likelihood of Additional Regulation}

\section{Level of Enforcement}

The question on how fully regulation was being enforced did not produce useable results. Many regulatory programs achieve high levels of compliance through voluntary participation, while others are enforced only on a complaint basis or with identified "bad actors." As a result, respondents' answers to this question ranged the full scale from $0 \%$ to $100 \%$ for most states. Respondents who placed the current or anticipated enforcement levels substantially below $100 \%$ almost uniformly cited limited agency funding as the reason. 


\section{Likelihood of Additional Regulation}

Answers to the question on the likelihood that additional regulation would be passed in the future were coded in five categories:

$$
\begin{aligned}
0 \% \text { to } 19 \% & =\text { Very Low } \\
20 \% \text { to } 39 \% & =\text { Less-Than-Even } \\
40 \% \text { to } 59 \% & =\text { Even } \\
60 \% \text { to } 79 \% & =\text { Better-Than-Even } \\
80 \% \text { to } 100 \% & =\text { Very High }
\end{aligned}
$$

The median responses varied from state to state. In general, however, respondents in the North placed high probabilities on passage of additional state water quality and endangered species regulation, but lower probabilities on passage of additional state forest practice regulation or county and municipal regulation (table 9). The specific type of regulation most frequently mentioned was legislation to identify and protect critical wildlife habitat. Respondents from northeast states that already have substantial municipal-level regulation frequently predicted that additional municipalities would pass ordinances. Respondents from north central states often predicted passage of comprehensive state forest practice acts, modeled after those presently in place in northeast states.

In the South, respondents placed the likelihood of additional regulation of all types at better-than-even or higher (table 9). Most respondents believed that some form of state BMPs, currently voluntary, would be made mandatory. Many also predicted passage of additional county-level timber harvesting ordinances, particularly at the fringes of urban growth areas.

Respondents in the Pacific Coast region considered chances for additional regulation better-thaneven or higher at the state level, but less-than-even at the local level (table 9). Again, most Pacific Coast states have comprehensive forest practice acts that limit the ability of counties and municipalities to pass independent enactments. Most frequently mentioned in this region were revisions to the state forest practice acts to address the cumulative effects and old growth issues.

In contrast to their peers elsewhere in the United States, respondents in the Rocky Mountain region--the region with the lowest level of state and local regulation-did not consider the probability for additional regulation of any type higher than even (table 9).

\section{Future Effect of State and Local Regulation on Private Timber Harvests}

In the North, respondents anticipated that reductions in private harvests of hardwood products attributable to state and local regulation would increase sharply over the next 10 years, from the present $1 \%$ - level to $10 \%$ or more (tables 5 and 10). They also predicted that regulation-induced reductions in private softwood harvests would roughly triple over the period, from $3 \%$ to $8 \%$ to $9 \%$ (tables 5 and 10 ). More stringent state water quality regulation was expected to be the principal cause of the changes,

\begin{tabular}{|c|c|c|c|c|}
\hline & North & South & $\begin{array}{c}\text { Pacific } \\
\text { Coast }\end{array}$ & $\begin{array}{l}\text { Rocky } \\
\text { Mountain }\end{array}$ \\
\hline $\begin{array}{l}\text { State Water Quality Regulation } \\
\text { State Endangered Species Regulation } \\
\text { State Forest Practice Regulation } \\
\text { County and Municipal Regulation }\end{array}$ & $\begin{array}{l}\checkmark \text { High } \\
>\text { Even } \\
<\text { Even } \\
<\text { Even }\end{array}$ & $\begin{array}{l}V \text { High } \\
V \text { High } \\
>\text { Even } \\
>\text { Even }\end{array}$ & $\begin{array}{l}>\text { Even } \\
\vee \text { High } \\
\vee \text { High } \\
<\text { Even }\end{array}$ & $\begin{array}{l}\text { Even } \\
\text { V Low } \\
\text { Even } \\
<\text { Even }\end{array}$ \\
\hline
\end{tabular}
followed by state endangered species and county and municipal regulation (tables 5 and 10).

Table 9.-Median estimates of the likelihood that additional regulation will be enacted within the next 10 years, by type of regulation and region.

\footnotetext{
Note: $V$ Low $=0 \%$ to $19 \%$ likelihood;

$<$ Even $=20 \%$ to $39 \%$ likelihood;

Even $=40 \%$ to $59 \%$ likelihood:

$>$ Even $=60 \%$ to $79 \%$ likelihood:

$V$ High $=80 \%$ to $100 \%$ likelihood.
} 
Respondents in the South also expected state and local regulation to cause broad and substantial reductions in private timber harvests. They predicted that harvests of both hardwood and softwood products would decline an additional $10 \%$ or more, from the current $3 \%$ level to $13 \%$ to $16 \%$ (tables 6 and 10 ). They attributed most of the anticipated change to increased state endangered species regulation, followed by state water quality and county and municipal regulation (tables 6 and 10).

In contrast, Pacific Coast respondents expected no further change in harvests of hardwood products (tables 7 and 10). They predicted that state endangered species and forest practice regulation would cause additional reductions in softwood harvests, however, from $6 \%$ to $8 \%$ for softwood pulpwood, and from $12 \%$ to $16 \%$ for softwood sawtimber (tables 7 and 10).

Table 10.-Median estimates of the future effect (in percent change) of state and local regulation on private timber harvests in the United States, by type of regulation, species and product group, and region.

Pacific Rocky

North South Coast Mountain

a. State Water Quality Regulation

Hardwood Pulpwood

Hardwood Sawtimber

Softwood Pulpwood

Softwood Sawtimber

b. State Endangered Species Regulation

Hardwood Pulpwood

Hardwood Sawtimber

Softwood Pulpwood

Softwood Sawtimber

$\begin{array}{rrrr}-4 & -5 & 0 & -1 \\ -5 & -6 & -1 & -1 \\ -2 & -7 & -3 & 0 \\ -3 & -9 & -7 & 0\end{array}$

c. State Forest Practice Regulation Hardwood Pulpwood +3 Hardwood Sawtimber Softwood Pulpwood Softwood Sawtimber

d. County and Municipal Regulation Hardwood Pulpwood Hardwood Sawtimber Softwood Pulpwood Softwood Sawtimber

e. Total Effect

Hardwood Pulpwood Hardwood Sawtimber Softwood Pulpwood Softwood Sawtimber $\begin{array}{ll}-6 & -7 \\ -8 & -6\end{array}$

$-8 \quad-6$

$-4 \quad-3$

$-4 \quad-4$

-2
-3
-2
-4


-
-
-3
-7
-
-2
-4
-2
-4

$-2$

$-3$

$-2$

0

0

$-2$

$-3$ 1 0

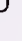

0

0

0

0

$-3-2$

$\begin{array}{ll}-3 & -2 \\ -2 & -3\end{array}$

$-2 \quad-3$

$-3 \quad-3$

$-10-14$

$-13-15$

$-8-13$

$-9 \quad-16$
Respondents in the Rocky Mountain region predicted that state water quality and endangered species regulation would cause an additional $1 \%$ decrease in the harvests of all timber products, from the current $1 \%$ to $3 \%$ level to $2 \%$ to $4 \%$ (tables 8 and 10 ).

The findings in this section may be considered tentative. They required a high level of speculation, and respondents' answers varied over a wide range. But they clearly suggest two main points. Respondents expect that, within the next several years, regulation-induced decreases in private timber harvests will reach or exceed the $10 \%$ level for the most important timber products in all but the Rocky Mountain region. Also, there is a high level of concern within the forestry community about current regulatory trends.

\section{Projected Effect of State and Local Regulation on Timber Supply and Price}

\section{Effect on Private Timber Supply}

TAMM projections made using the Delphi survey results indicate that state and local regulation should cause only slight changes in private supply of hardwood products, but can be expected to have a marked effect on the supply of softwood sawtimber products.

Private supply of hard wood non-sawtimber products $^{4}$ is projected to stay within $1 \%$ of the baseline supply level, in all regions, over the entire projection period (table 11). Supply of hardwood sawtimber products is projected to remain within $4 \%$ of the baseline level (table 12). In the North, projected supply of hardwood non-sawtimber products remains slightly above the baseline through the year 2040, largely offsetting below-baseline supply projected for sawtimber products (tables 11 and 12). In the South, projected supply of hardwood products averages nearly 20 million cubic feet per year above the baseline, marking an apparent shift from softwood to hardwood products (tables 11 and 12). Regulation is projected to have no additional effect on hardwood product supply in the Pacific Coast or Rocky Mountain regions (tables 11 and 12).

\footnotetext{
4TAMM model output combines pulpwood, chemical wood, and fuelwood into a category titled "non-sawtimber products;" it combines sawtimber, plywood peeler logs, and such miscellaneous industrial products as poles, piling, posts, mine timbers and cooperage into a category titled "sawtimber products."
} 
Table 11.-Projected effect of state and local regulation on annual supply (in million cubic feet) of hardwood non-sawtimber products from private forest lands, 1990 through 2040, by decade and region.

$19902000 \quad 2010 \quad 2020 \quad 2030 \quad 2040$

\section{a. North}

Baseline Projected Harvest

Projected Harvest Including Regulation

Estimated Effect of Regulation

Percent

b. South

Baseline Projected Harvest

Projected Harvest Including Regulation

Estimated Effect of Regulation

Percent

c. Pacific Coast

Baseline Projected Harvest

Projected Harvest Including Regulation

Estimated Effect of Regulation

Percent

\section{d. Rocky Mountain}

Baseline Projected Harvest

Projected Harvest Including Regulation

Estimated Effect of Regulation

Percent

$\begin{array}{rrrrrr}2213 & 2709 & 3105 & 3498 & 3836 & 4276 \\ 2213 & 2718 & 3125 & 3536 & 3868 & 4298 \\ - & 9 & 20 & 38 & 32 & 22 \\ - & 0 \% & 1 \% & 1 \% & 1 \% & 1 \%\end{array}$

$\begin{array}{rrrrrr}1719 & 2279 & 2705 & 2771 & 2929 & 2983 \\ 1719 & 2281 & 2709 & 2779 & 2929 & 2976 \\ - & 2 & 4 & 8 & 0 & -7 \\ - & 0 \% & 0 \% & 0 \% & 0 \% & 0 \% \\ & & & & & \\ 108 & 160 & 188 & 209 & 246 & 252 \\ 108 & 160 & 188 & 209 & 246 & 252 \\ - & 0 & 0 & 0 & 0 & 0 \\ - & 0 \% & 0 \% & 0 \% & 0 \% & 0 \%\end{array}$

$\begin{array}{rrrrrr}13 & 11 & 20 & 28 & 41 & 49 \\ 13 & 11 & 20 & 28 & 41 & 49 \\ - & 0 & 0 & 0 & 0 & 0 \\ - & 0 \% & 0 \% & 0 \% & 0 \% & 0 \%\end{array}$

Table 12.-Projected effect of state and local regulation on annual supply (in million cubic feet) of hardwood sawtimber products from private forest lands, 1990 through 2040 , by decade and region.

\section{$\begin{array}{llllll}1990 & 2000 & 2010 & 2020 & 2030 & 2040\end{array}$}

\section{a. North}

Baseline Projected Harvest

Projected Harvest Including Regulation

Estimated Effect of Regulation

Percent

b. South

Baseline Projected Harvest
Projected Harvest Including Regulation
Estimated Effect of Regulation

Percent

c. Pacific Coast

Baseline Projected Harvest

Projected Harvest Including Regulation

Estimated Effect of Regulation

Percent

$\begin{array}{rrrrrr} & & & & & \\ 1126 & 1079 & 1057 & 1049 & 1051 & 1073 \\ 1126 & 1065 & 1028 & 1014 & 1012 & 1030 \\ - & -14 & -29 & -35 & -39 & -43 \\ - & -1 \% & -3 \% & -3 \% & -4 \% & -4 \% \\ & & & & & \\ 1006 & 1200 & 1388 & 1537 & 1627 & 1730 \\ 1006 & 1209 & 1406 & 1560 & 1651 & 1747 \\ - & 9 & 18 & 23 & 24 & 17 \\ - & 1 \% & 1 \% & 1 \% & 1 \% & 1 \% \\ & & & & & \\ 98 & 126 & 136 & 154 & 146 & 151 \\ 98 & 126 & 136 & 154 & 146 & 151 \\ - & 0 & 0 & 0 & 0 & 0 \\ - & 0 \% & 0 \% & 0 \% & 0 \% & 0 \%\end{array}$

d. Rocky Mountain

Baseline Projected Harvest

Projected Harvest Including Regulation

Estimated Effect of Regulation

Percent

$\begin{array}{rrrrrr}1 & 0 & 0 & 0 & 0 & 0 \\ 1 & 0 & 0 & 0 & 0 & 0 \\ - & 0 & 0 & 0 & 0 & 0 \\ - & 0 \% & 0 \% & 0 \% & 0 \% & 0 \%\end{array}$


State and local regulation also is projected to raise private supply of softwood non-sawtimber products slightly above the baseline level through the projection period. In the North and South, softwood nonsawtimber supply is projected to exceed the baseline by up to $2 \%$, for an average of roughly 12 million cubic feet per year (table 13). Projected supply in the Pacific Coast and Rocky Mountain regions ranges as high as $6 \%$ above baseline, for an average of just under 3 million cubic feet per year (table 13). These figures appear to indicate another shift, from large to small softwood products.

In contrast, regulation is projected to push private supply of softwood sawtimber products well below the baseline level. The effect is concentrated in the South and Pacific Coast regions. In the South, supply of softwood sawtimber products is projected to average $15 \%$, or 605 million cubic feet per year, below the baseline through the year 2040 (table 14). Supply in the Pacific Coast region is projected to average nearly $3 \%$, or 40 million cubic feet per year, below the baseline (table 14). Some production is projected to shift to the North and Rocky Mountain regions; but total projected supply of softwood sawtimber products remains between 360 and 814 million cubic feet per year below the baseline level (table 14).

\section{Effect on U.S. Timber Supply}

Tables 15 and 16 show, respectively, projected annual U.S. supply of hardwood and softwood sawtimber products. Close comparison with tables 12 and 14, which show projected annual private supply, reveals that the volume estimates for the effect of regulation are virtually identical between the two sets of tables. This indicates that timber buyers cannot expect the effect of regulation on private timber supply to be moderated by increased harvests from public forests. Instead, it is projected to pass essentially unchanged to timber markets (tables 12, 14, 15, and 16).

\section{Effect on Stumpage Prices}

The TAMM model results indicate that, in addition to diminished overall timber supply, state and local regulation can be expected to generate real increases in timber stumpage prices. Tables 17 and 18 show, respectively, projected average stumpage prices for hardwood and softwood sawtimber products, expressed in constant 1982 dollars. Prices of all sawtimber products are projected to rise sharply by the year 2000, to between $15 \%$ and $25 \%$ above the baseline level (tables 17 and 18). Hardwood sawtimber prices in the North and South are projected to continue rising relative to the baseline until 2010, then begin reapproaching baseline prices at the rate of one or two percentage points each decade (table 17).

Projected prices of softwood sawtimber products do not follow a common pattern. In the North, they are projected to begin slowly reapproaching the baseline price level after the year 2000 (table 18). In the South, they are projected to continue rising relative to baseline prices until about 2010, then stabilize at $15 \%$ to $17 \%$ above the baseline (table 18). In the Pacific Coast region, softwood sawtimber prices are projected to remain some $20 \%$ above the baseline through the end of the projection period (table 18). In the Rocky Mountain region, they are projected to continue rising relative to the baseline beyond the year 2010 , then stabilize at $25 \%$ to $30 \%$ above baseline prices (table 18).

\section{CONCLUSIONS}

State and local regulation of private forest practices has increased dramatically over the past 10 years. At the state level, the water quality laws in about one-fourth of the 50 states specifically regulate forest operations, while those of the remaining states are written broadly enough to cover forestry by implication. Forty-four states have passed endangered species legislation augmenting federal law, and 21 states regulate forest practices.

Regulation at the county and municipal level has increased more than four-fold in the past 10 years, from 116 enactments before 1983, to 527 enactments in 1992. These local enactments differ widely in their stringency and their potential effect on timber supply. Each, however, can be placed into one of five categories according to its regulatory objective: public property protection, tree protection, special feature protection, environmental protection, and timber harvesting. Most local regulation in the North RPA region has been enacted at the municipal level, and most regulation in the South at the county level. 
Table 13.-Projected effect of state and local regulation on annual supply (in million cubic feet) of softwood non-sawtimber products from private forest lands, 1990 through 2040, by decade and region.

$\begin{array}{llllll}1990 & 2000 & 2010 & 2020 & 2030 & 2040\end{array}$

a. North

Baseline Projected Harvest

Projected Harvest Including Regulation

Estimated Effect of Regulation

Percent

b. South

Baseline Projected Harvest

Projected Harvest Including Regulation

Estimated Effect of Regulation

Percent

c. Pacific Coast

Baseline Projected Harvest

Projected Harvest Including Regulation

Estimated Effect of Regulation

Percent

d. Rocky Mountain

Baseline Projected Harvest

Projected Harvest Including Regulation

Estimated Effect of Regulation

Percent

$\begin{array}{rrrrrr}513 & 707 & 867 & 965 & 999 & 985 \\ 513 & 709 & 873 & 980 & 1017 & 997 \\ - & 2 & 6 & 15 & 18 & 12 \\ - & 0 \% & 1 \% & 2 \% & 2 \% & 1 \% \\ & & & & & \\ 1995 & 2250 & 2354 & 2681 & 3123 & 3525 \\ 1995 & 2251 & 2357 & 2739 & 3126 & 3526 \\ - & 1 & 3 & 58 & 3 & 1 \\ - & 0 \% & 0 \% & 2 \% & 0 \% & 0 \% \\ & & & & & \\ 264 & 345 & 437 & 479 & 565 & 631 \\ 264 & 347 & 460 & 481 & 564 & 629 \\ - & 2 & 23 & 2 & -1 & -2 \\ - & 1 \% & 5 \% & 0 \% & 0 \% & 0 \% \\ & & & & & \\ 33 & 33 & 49 & 65 & 87 & 91 \\ 33 & 35 & 50 & 66 & 86 & 92 \\ - & 2 & 1 & 1 & -1 & 1 \\ - & 6 \% & 2 \% & 2 \% & -1 & 1 \% \\ & & & & & \end{array}$

Table 14.-Projected effect of state and local regulation on annual supply (in million cubic feet) of softwood sawtimber products from private forest lands, 1990 through 2040, by decade and region.

\section{$\begin{array}{llllll}1990 & 2000 & 2010 & 2020 & 2030 & 2040\end{array}$}

a. North

Baseline Projected Harvest

Projected Harvest Including Regulation

Estimated Effect of Regulation

Percent

b. South

Baseline Projected Harvest

Projected Harvest Including Regulation

Estimated Effect of Regulation

Percent

c. Pacific Coast

Baseline Projected Harvest

Projected Harvest Including Regulation

Estimated Effect of Regulation

Percent

d. Rocky Mountain

Baseline Projected Harvest

Projected Harvest Including Regulation

Estimated Effect of Regulation

Percent

$\begin{array}{rrrrrr}296 & 374 & 423 & 421 & 415 & 406 \\ 296 & 378 & 429 & 430 & 425 & 408 \\ - & 4 & 6 & 9 & 10 & 2 \\ - & 1 \% & 1 \% & 2 \% & 2 \% & 0 \% \\ & & & & & \\ 2546 & 3312 & 3439 & 4419 & 4686 & 4374 \\ 2546 & 2975 & 2967 & 3654 & 3873 & 3736 \\ - & -337 & -472 & -765 & -813 & -638 \\ - & -10 \% & -14 \% & -17 \% & -17 \% & -15 \% \\ & & & & & \\ 2066 & 1503 & 1339 & 1324 & 1449 & 1911 \\ 2066 & 1463 & 1275 & 1310 & 1401 & 1877 \\ - & -40 & -64 & -14 & -48 & -34 \\ - & -3 \% & -5 \% & -1 \% & -3 \% & -2 \% \\ & & & & & \\ 359 & 356 & 311 & 244 & 277 & 327 \\ 359 & 369 & 340 & 288 & 314 & 342 \\ - & 13 & 29 & 44 & 37 & 15 \\ - & 4 \% & 9 \% & 18 \% & 13 \% & 5 \%\end{array}$


Table 15.-Projected effect of state and local regulation on annual U.S. supply (in million cubic feet) of hardwood sawtimber products, 1990 through 2040 , by decade and region.

$1990 \quad 2000 \quad 2010 \quad 2020 \quad 2030 \quad 2040$

a. North

Baseline Projected Harvest

Projected Harvest Including Regulation

Estimated Effect of Regulation

Percent

b. South

Baseline Projected Harvest

Projected Harvest Including Regulation

Estimated Effect of Regulation

Percent

c. Pacific Coast

Baseline Projected Harvest

Projected Harvest Including Regulation

Estimated Effect of Regulation

Percent

$\begin{array}{rrrrrr}1233 & 1198 & 1179 & 1174 & 1179 & 1203 \\ 1233 & 1184 & 1150 & 1139 & 1140 & 1160 \\ - & -14 & -29 & -35 & -39 & -43 \\ - & -1 \% & -2 \% & -3 \% & -3 \% & -4 \% \\ & & & & & \\ 1054 & 1245 & 1433 & 1583 & 1674 & 1776 \\ 1054 & 1254 & 1452 & 1606 & 1698 & 1794 \\ - & 9 & 19 & 23 & 24 & 18 \\ - & 1 \% & 1 \% & 1 \% & 1 \% & 1 \% \\ & & & & & \\ 140 & 152 & 162 & 180 & 172 & 177 \\ 140 & 152 & 162 & 180 & 172 & 177 \\ - & 0 & 0 & 0 & 0 & 0 \\ - & 0 \% & 0 \% & 0 \% & 0 \% & 0 \%\end{array}$

d. Rocky Mountain

Baseline Projected Harvest

Projected Harvest Including Regulation

Estimated Effect of Regulation

Percent

$\begin{array}{rrrrrr}4 & 4 & 4 & 5 & 5 & 5 \\ 4 & 4 & 4 & 5 & 5 & 5 \\ - & 0 & 0 & 0 & 0 & 0 \\ - & 0 \% & 0 \% & 0 \% & 0 \% & 0 \%\end{array}$

Table 16.-Projected effect of state and local regulation on annual U.S. supply (in million cubic feet) of softwood sawtimber products, 1990 through 2040 , by decade and region.

\section{$\begin{array}{llllll}1990 & 2000 \quad 2010 & 2020 & 2030 & 2040\end{array}$}

a. North

Baseline Projected Harvest

Projected Harvest Including Regulation

Estimated Effect of Regulation

Percent

b. South

Baseline Projected Harvest

Projected Harvest Including Regulation

Estimated Effect of Regulation

Percent

$\begin{array}{rrrrrr}334 & 416 & 475 & 476 & 471 & 463 \\ 334 & 421 & 482 & 484 & 482 & 466 \\ - & 5 & 7 & 8 & 11 & 3 \\ - & 1 \% & 1 \% & 2 \% & 2 \% & 1 \% \\ & & & & & \\ 2766 & 3413 & 3645 & 4630 & 4903 & 4593 \\ 2766 & 3177 & 3172 & 3865 & 4089 & 3956 \\ - & -336 & -473 & -765 & -814 & -637 \\ - & -10 \% & -13 \% & -17 \% & -17 \% & -14 \% \\ & & & & & \\ 3459 & 2282 & 2134 & 2124 & 2255 & 2711 \\ 3459 & 2242 & 2071 & 2113 & 2201 & 2679 \\ - & -40 & -63 & -11 & -54 & -32 \\ - & -2 \% & -3 \% & -1 & -2 \% & -1 \% \\ & & & & & \\ 861 & 777 & 745 & 694 & 740 & 807 \\ 861 & 789 & 776 & 740 & 783 & 824 \\ - & 12 & 31 & 46 & 43 & 17 \\ - & 2 \% & 4 \% & 7 \% & 6 \% & 2 \%\end{array}$


Table 17.-Projected effect of state and local regulation on average real stumpage prices (in 1982 dollars) for hardwood sawtimber products, 1990 through 2040 , by decade and region.

$1990 \quad 2000 \quad 2010 \quad 2020 \quad 2030 \quad 2040$

a. North

Baseline Stumpage Price

Projected Price Including Regulation

Estimated Effect of Regulation

Percent

b. South

Baseline Stumpage Price

Projected Price Including Regulation

Estimated Effect of Regulation

Percent

c. Pacific Coast

Baseline Stumpage Price

Projected Price Including Regulation

Estimated Effect of Regulation

Percent

d. Rocky Mountain

Baseline Stumpage Price

Projected Price Including Regulation

Estimated Effect of Regulation

Percent

$\begin{array}{rrrrrr}112 & 145 & 147 & 157 & 172 & 190 \\ 112 & 180 & 194 & 203 & 217 & 236 \\ - & 35 & 47 & 46 & 45 & 46 \\ - & 24 \% & 32 \% & 29 \% & 26 \% & 24 \%\end{array}$

$\begin{array}{rrrrrr}54 & 70 & 82 & 96 & 126 & 156 \\ 54 & 86 & 107 & 125 & 161 & 196 \\ - & 16 & 25 & 29 & 35 & 40 \\ - & 23 \% & 30 \% & 30 \% & 28 \% & 26 \%\end{array}$

Table 18.-Projected effect of state and local regulation on average real stumpage prices (in 1982 dollars) for softwood sawtimber products, 1990 through 2040 , by decade and region.

$\begin{array}{llllll}1990 & 2000 & 2010 & 2020 & 2030 & 2040\end{array}$

a. North

Baseline Stumpage Price

Projected Price Including Regulation

Estimated Effect of Regulation

Percent

b. South

Baseline Stumpage Price

Projected Price Including Regulation

Estimated Effect of Regulation

Percent

c. Pacific Coast

Baseline Stumpage Price
Projected Price Including Regulation

Estimated Effect of Regulation

Percent

d. Rocky Mountain

Baseline Stumpage Price

Projected Price Including Regulation

Estimated Effect of Regulation

Percent

$\begin{array}{rrrrrr}54 & 81 & 133 & 158 & 185 & 206 \\ 54 & 97 & 155 & 182 & 212 & 231 \\ - & 16 & 22 & 24 & 27 & 25 \\ - & 20 \% & 17 \% & 15 \% & 15 \% & 12 \% \\ & & & & & \\ 131 & 216 & 232 & 266 & 255 & 259 \\ 131 & 270 & 297 & 307 & 292 & 302 \\ - & 54 & 65 & 41 & 37 & 43 \\ - & 25 \% & 28 \% & 15 \% & 15 \% & 17 \% \\ & & & & & \\ 159 & 211 & 246 & 246 & 222 & 226 \\ 159 & 252 & 292 & 297 & 267 & 269 \\ - & 41 & 46 & 51 & 45 & 43 \\ - & 19 \% & 19 \% & 21 \% & 20 \% & 19 \%\end{array}$

$\begin{array}{rrrrrr}47 & 138 & 155 & 153 & 150 & 152 \\ 47 & 159 & 194 & 199 & 195 & 190 \\ - & 21 & 39 & 46 & 45 & 38 \\ - & 15 \% & 25 \% & 30 \% & 30 \% & 25 \%\end{array}$


Local regulation has increased most rapidly in the North and South regions, and in the three categories-special feature protection, environmental protection, and timber harvesting-with the greatest potential effect on timber management and harvests. Timber harvesting ordinances represent two-fifths of all local ordinances identified in 1992; special feature and environmental protection ordinances account for about one-fifth each.

The study results indicate that state and local regulation of private forest practices can be expected to increase further. Local ordinances in particular should become more prevalent. The primary reasons for this conclusion are demographic. The population is continuing to shift from urban to more rural settings. Former urbanites have few ties to traditional rural agriculture- and forest-based economies. They generally relocate for a lifestyle which includes high amenity values, and quickly seek a public response when they believe this lifestyle is jeopardized by unregulated forestry operations.

General public concern over the environment also continues to grow. This trend is important, because public interest has increased the pressure on elected officials to take whatever action is needed to ensure that the environment is protected from abusive practices, including perceived abusive forestry practices.

On the opposite side, some factors could slow the future spread of local forestry regulation in some states. The "checkerboard" pattern of regulation created by diverse local ordinances could so disrupt the forest economy that the forestry community would press state legislatures for state-level forest regulation preempting or limiting local regulatory authority. This already is occurring, on a limited scale, in northeast states. Another factor that could slow the spread of local ordinances is public education. Forestry operations sometimes have been criticized, even though they were carried out in a responsible and professional way, because they simply look bad. Better informed citizens could result in the circumvention of some local regulation that otherwise would be enacted.

The Delphi survey results indicate that state and local regulation places the greatest constraint on current timber harvests in the Pacific Coast region. There, estimates of regulation-related decreases in private harvests ranged from $4 \%$ for hardwood pulpwood to $12 \%$ for softwood sawtimber. In all other regions, state and local regulation currently causes reductions in private harvests estimated at $1 \%$ to $4 \%$. As one respondent noted, however, even a small reduction in harvests can result in shortages in markets where timber removals already equal or exceed growth.

Regulation appears to have a greater effect on current harvests from nonindustrial private holdings in the North and from forest industry land in the South. In the Pacific Coast region, nonindustrial private lands are more affected than forest industry by the aspects of regulation that reduce softwood sawtimber harvests. In the Rocky Mountain region, regulation-induced reductions in hardwood harvests occur entirely on nonindustrial private lands, while decreases in softwood harvests are concentrated on forest industry holdings.

Respondents in all regions except the Rocky Mountain considered it a virtual certainty they will face additional regulation in the immediate future.

Respondents in the Pacific Coast and Rocky Mountain regions anticipated little additional effect from state and local regulation within the next 10 years. In contrast, respondents in the North and South expected further sharp reductions in private timber harvests, ranging from $9 \%$ to $12 \%$ for hardwood products and from $5 \%$ to $13 \%$ for softwood. If these predictions are realized, reductions in private timber harvests will reach the $10 \%$ to $15 \%$ level or greater for virtually all regionally important timber products.

The survey results demonstrated that regulation can act to increase or decrease current timber supply from private forest lands. Respondents warned, however, that an increase in current supply can be associated with either an increase in long-term supply (as with state reforestation requirements and incentives), or a decrease (as when landowners accelerate harvests to avoid new requirements they consider onerous). At present, only the reforestation provisions of state forest practice laws are associated with both current and long-term increases in timber supply. All the other types of regulation surveyed are associated with reduced long-term supply. This is particularly the case for state water quality regulation, which was a leading factor in current and anticipated timber supply reductions in all regions.

The Timber Assessment Marketing Model (TAMM) runs based on the Delphi survey results project three modest shifts in timber markets, in response to the anticipated changes in regulation: from large products to small, from softwood prod- 
ucts to hardwood, and from the South and Pacific Coast regions to the North and Rocky Mountain. The projections indicate, however, that the bulk of the response will be in terms of diminished softwood sawtimber supply and increased real stumpage prices. The supply of softwood sawtimber products is projected to average 10\%-roughly 610 million cubic feet per year-below the baseline level through the year 2040. This projection dwarfs the modest improvements seen for non-sawtimber and hardwood products, which total some 40 million cubic feet per year.

Comparison of the projections for private and total United States harvests indicates the decreases in private timber supply will not be moderated by increased harvests from public forests, but will pass essentially unchanged to timber markets. Timber stumpage prices are projected to increase sharply by the year 2000, and to remain substantially above baseline price levels through 2040. Projected stumpage prices for hardwood saw timber products peak at $30 \%$ to $35 \%$ above baseline prices and continue about $25 \%$ higher. Projected stumpage prices for softwood sawtimber products follow a different pattern in each region, but remain an average of $20 \%$ above baseline levels through the end of the projection period.

Despite their relatively small size, the shifts in product size, species class, and region have implications for economic and natural resource policy. A shift to smaller products would result in increased harvesting and handling costs. Also, product quality and yield would decline because of the greater proportion of juvenile wood. A shift to hardwood products is likely to encounter problems of substitutability, but, at the same time, should improve incentives to manage hardwood timber. A shift out of the South and Pacific Coast regions would cause further economic dislocations to traditionally timber-dependent communities. The much larger shifts projected for softwood sawtimber supply and price, call for preparation in a number of policy areas, including regional economics, industrial stability, international trade, environmental quality, and forest management assistance.

\section{LITERATURE CITED}

Baughman, M., and P. Ellefson. 1983. Minnesota's county forests: A Delphi study of options for pro- gram funding, sale of timber, and land ownership. State Bulletin AD-SB-2194. University of Minnesota Agricultural Experiment Station, St. Paul, Minnesota. $44 \mathrm{p}$.

Gregersen, Hans M., Allan L. Lundgren, Pamela J. Jakes, and David N. Bengston. 1989. Identifying emerging issues in forestry as a tool for research planning. General Technical Report NC-137. USDA Forest Service, North Central Forest Experiment Station, St. Paul, Minnesota. 21 p.

Guldin, R.W. 1988. An analysis of the Water Situation in the United States: 1989-2040. USDA Forest Service, Washington, D.C. 378 p.

Henderson, Douglas, John Gray, John Greene, and Mina Marsh. 1992. Facing the future: Critical issues in the management of Arkansas's forest resources, a discussion paper. Rural and Resource Development Series. Winrock International Institute for Agricultural Development, Morrilton, Arkansas. $61 \mathrm{p}$.

Hickman, Clifford A., and Christopher E. Martus. 1991. Local regulation of private forestry in the eastern United States. Pages 73-87 in Environmental concerns, government regulations, new technology and their impact on southern forestry: Proceedings of the Southern Forest Economics Workshop, February 20-22. Washington, D.C.

Martus, Christopher E. 1992. The distribution and objectives of local forestry-related ordinances in the United States. Masters thesis. Virginia Polytechnic Institute and State University, Blacksburg, Virginia. 308 p.

National Wildlife Federation. 1992. 1992 conservation directory. 37 th Edition. National Wildlife Federation, Washington, D.C. 398 p.

Quarles, Steven P., John A. Maclead, and Thomas R. Lundquist. 1991. The endangered species act and its application to private lands. Technical Bulletin No. 91-06. American Forest Resources Alliance, Washington, D.C., 36 p.

Schuster, Ervin G., Sidney S. Frissell, Eldon E. Baker, and Robert S. Loveless, Jr. 1985. TheDelphi method: Application to elk habitat quality. Research Paper INT-353. USDA Forest Service, Intermountain Research Station, Ogden, Utah. 32 p.

Shafer, Elwood L., George H. Moeller, and Russell E. Getty. 1974. Future leisure environments. Research Paper NE-301. USDA Forest Service, Northeastern Forest Experiment Station, Upper Darby, Pennsylvania. $16 \mathrm{p}$. 
Siegel, W.C. 1990. Legislative regulation of private forestry practices in the United States-recent developments. In: Forestry Legislation, Report of IUFRO Working Party 54.08-03; Zurich, Switzerland: 349-364.
Waddell, Karen L., Daniel D. Oswald, and Douglas S. Powell. 1989. Forest statistics of the United States, 1987. Resource Bulletin PNW-RB-168. USDA Forest Service, Pacific Northwest Research Station, Portland, Oregon. 106 p. 


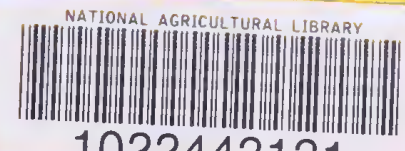

1022443131

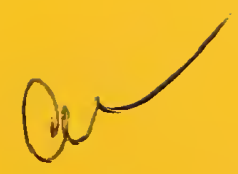




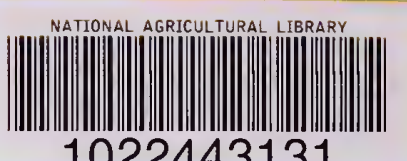

1022443131 